Journal of English Language Teaching

\title{
Analyzing English for Academic Purposes textbooks: A study of Intercultural Issues
}

\section{Yulong Li ${ }^{1}$, Pengfei Yao ${ }^{\varpi, 2}$, Bo Hu$^{1}$}

${ }^{1}$ Faculty of Humanities and Social Sciences, City University of Macau, Macau SAR, China

${ }^{2}$ College of Teacher Education, East China Normal University, Shanghai, China

\section{Article Info}

Article History:

Received in 14 March

2020

Approved in 1 July 2020

Published in 30 July 2020

Keywords: EAP textbook; intercultural issues; EAP in China; critical EAP

\begin{abstract}
An increase of English for Academic Purposes (EAP) teaching in China has resulted in a surge of EAP textbooks on the market. However, there has been little accompanying interest in how well intercultural issues are handled and presented in these publications. Accordingly, the present study employs Chinese students' Cultures of Learning (CoL) and contrastive rhetoric $(\mathrm{CR})$ as reflection points in the analysis of the content, production, and consumption of two series of EAP textbooks adapted from overseas textbooks. Findings revealed that intercultural differences are not given due recognition in the textbooks which in some cases can lead to confusion and misunderstanding. Meanwhile, the teachers involved in the study, as users of the other textbook series, were found to treat the textbooks only as a supplementary EAP teaching resource. Moreover, the continued confusion on the part of some of the students involved in the study highlighted the desirability for future textbooks to render intercultural differences in a critical EAP manner.
\end{abstract}

(C) 2020 Universitas Negeri Semarang

Correspondent Address: p-ISSN 2252-6706 | e-ISSN 2721-4532

College of Teacher Education, East China Normal University,

NO.3663, North Zhongshan Rd, Shanghai, China, 200062

E-mail: fieldine@126.com 


\section{INTRODUCTION}

In order to satisfy the increasing demand for EAP lessons at universities, many Chinese academic publishers have invited scholars to produce new EAP textbooks, or to adapt existing textbooks originally published in other countries, after purchasing the relevant copyright. At the time of this current research project, there were at least eight series of EAP textbooks on the market, written by local Chinese scholars. However, little studies were conducted on the Chinese EAP textbooks, particularly the intercultural aspects of them. Intercultural issues in EAP is important because, when first introduced to EAP, students from non-Western backgrounds can encounter varying degrees of academic shock (de Chazal, 2014), caused by unfamiliar academic conventions, and different study strategies (Singh and Doherty, 2004; de Chazal, 2014). Both Cortazzi and Jin (1996), and Parris-Kidd and Barnett (2011) employed the concept of "cultures of learning" (CoL) to explain the challenges Chinese students sometimes encounter in international context, and linguists have employed notions of contrastive rhetoric (CR), whereby Chinese students' English academic writing is influenced by their native cultural and linguistic heritage (Kirkpatrick and $\mathrm{Xu}$, 2012). Sign and Doherty (2004) warned EAP teachers that their students' intercultural differences can alienate students in their study of English academic practices, as EAP classes are nodes of academic and cultural exchange (de Chazal, 2014) that represent the initial contact zone for international students (Sign and Doherty, 2004).

However, O'Dwyer (2017) argued that the challenges these Chinese students encounter in EAP should not necessarily be associated with their native cultural influences, as they might also simply be the result of a lack of training. He stressed that many typologies of the study styles of students with a Confucius heritage cultural background are reductive and essentialist (O'Dwyer, 2017), although this view was not based on empirical findings. Despite the on-going debate over whether or not intercultural differences influence Chinese students' EAP learning, there are currently few empirical studies concerning intercultural issues in EAP (Aguilar, 2018). In this regard, the current study aims to contribute to the field by solving the following problems: How are the students' home and target cultures, concerning CoL and CR, represented in the contents of the chosen EAP textbooks published in China? How do the EAP textbook authors/editors perceive the processing of intercultural differences in the EAP textbooks they designed? How do teachers perceive and operationalise intercultural differences in teaching EAP, in line with the textbooks? To what extent are the challenges encountered by the students related to intercultural differences, and to what extent were they resolved using the textbooks?

\section{The notion of Chinese CoL in EAP teaching}

The concern about intercultural differences for Chinese students studying EAP emanated from the promoters of CoL and CR. Via the concept of CoL, Cortazzi and Jin (1996, p.169) focused on the possible intercultural differences students face when studying in a new academic context: "many behaviours in the language classroom are set within taken-for-granted frameworks of expectations, attitudes, values, and beliefs about what constitutes good learning, about how to teach or learn, whether and how to ask questions, what textbooks are for." Meanwhile, Parris-Kidd and Barnett (2011) employed social distance (SD) and academic distance (AD) to explain the specific challenges that Chinese students may face in CoL.

According to Parris-Kidd and Barnett (2011, p.178), SD "between cultures of learning can be identified through the tensions students experience regarding complying with the teacher's expectations of participation in the new setting." For example, Chinese students are reluctant to answer their teachers' questions in class, for fear of losing face in the presence of others (Jin and Cortazzi, 2006; Liu and Littlewood, 1997). Furthermore, Chinese students have been found to be resistant to entering into debates with their fellow students for fear of encountering embarrassment and conflict (Durkin, 2011; Grimshaw, 2007; Nisbett, 2003). Likewise, Jin and Cortazzi (1998) found that Chinese learners favour a learning-listening approach. In contrast, an openness to debate, and active participation in classroom discussion is valued in Western academic culture (Parris-Kidd and Bartnett, 2011). Furthermore, students of Chinese origin have been found to strictly adhere to their teachers' and parents' supervision during their extracurricular homework time (Salili, 1996), but are expected to be more autonomous in expanding their reading, searching databases, and even researching after classes within the EAP context (Emerson, 2018). For many Chinese students, books represent truth and authority, and they are required to memorise much of the books' content (Maley, 1996). However, in the case of EAP learning, books remain open to critical comment (Shon, 2015). 
$\mathrm{AD}$ is generally referred to as the gap between what is considered valid learning in the students' home culture, and that of the target culture (Parris-Kidd and Barnett, 2011). For instance, Chinese students tend to be test-score-oriented (Jin and Cortazzi, 2003), and Gao (1998) noted that Chinese students rank examination preparation as one of their top priorities with regard to their expectations from teachers. In addition, rote learning is a commonly employed study method for Chinese students (Rao and Chan, 2009; Li and Cutting, 2011), as it is believed to bring about in-depth understanding (Watkins, 2009). However, this form of learning does not correlate with EAP teachers' expectations (Singh and Doherty, 2004). Meanwhile, Maley (1996, p.104-105) found that when reading in English, most Chinese university students resort to a "word by word, phrase by phrase approach, while noting points of vocabulary, syntax, style and content along the way." Many scholars, however, do not recommend this approach for obtaining critical academic reading skills (Shon, 2015; Wallace and Wray, 2016).

The characteristics of the Chinese learning style noted here may be due to Confucianism, which advocates interpersonal harmony and rapport; thus, the Chinese sense of individualism is weaker than that of their Western counterparts (Scollon, 1991). This means that many Chinese students conceive of critical thinking, which is considered to be a desirable form of reasoning in Western academic writing, as being too confrontational and uncomfortable (Durkin, 2011). Moreover, Chinese students' conduct, and beliefs about plagiarism, also differ from those of their Western counterparts (Bloch, 2008), since, from a relativist perspective, an individual's academic and ethical judgments are underpinned by social and cultural guidelines and parameters (Yang, 2012; Jung, 2009). In sum, if these these distances are not addressed, Chinese students' ability to adapt to academic learning may be hindered (Parris-Kidd \& Barnett, 2011).

\section{The concept of $C R$ in the academic context}

The concept of CR was promoted by Connor (1996) to explain the challenges encountered by the second language (L2) learners in writing from the perspective of the strategies they would employ in their first language rhetoric. This represented a ground-breaking concept in L2 education at the time of its creation (McIntosh, Connor and Gokpinar-Shelton, 2017), due to its pedagogical implications for teachers concerning the teaching of various rhetorical preferences, and ways of guiding their students via customised teaching materials (Connor, Ene and Traversa, 2016).

$\mathrm{CR}$ is helpful in pointing out certain distinctive characteristics in a given culture's way of writing, such as the Chinese way of referencing and persuading. When composing English essays, many Chinese students routinely make references to history, poems, narratives, and proverbs (Matalene, 1985), a practice transferred from the Chinese writing tradition (Connor, 1996) for ornamenting and exhibiting authority (Matalene, 1985). However, in English academic writing, referencing is required to be disciplinary. Furthermore, the Chinese tend to be indirect and ambiguous in their writing, sometimes using analogies and anecdotes to express their opinions (Kaplan, 1966; Matalene, 1985), which is contradictory to the explicitness advocated in English academic writing (Durkin, 2011). According to Kirkpatrick and Xu (2012), this indirect approach originated with Gui Guzi, a Chinese rhetoric expert and philosopher, who lived during the Warring States Period (475$221 \mathrm{BC}$ ), and who claimed that indirect rhetoric is a default persuasive style for use when employing tact, while considering an explicit approach to be unusually confrontational. On the other hand, as an increasing number of Chinese scholars are publishing in English, there is a growing recognition that such forms of argumentation are seen as archaic.

Generally speaking, the supporters of $\mathrm{CoL}$ and $\mathrm{CR}$ assume that raising awareness of these intercultural differences is necessary for enabling international students to attain a better selfawareness when learning English academic traditions (Ryan, 2011), and is similarly beneficial for EAP teachers for better understanding the challenges with which their students contend, and for providing them with appropriate assistance (Connor, 2011).

\section{Opposition to the intercultural differences in EAP}

Opponents of the theory of CR criticise it as being created from the language of L2 learners, rather than that of expert L2 users (Connor, 2011; McIntosh, Connor and Gokpinar-Shelton, 2017). Because Chinese academic rhetoric has changed and evolved over thousands of years, employing a static view that essentialises Chinese rhetoric and its potential influence on students' English academic writing, which is what CR does, can be considered an over-simplified approach (Kirkpatrick and $\mathrm{Xu}, 2012$ ). Underscoring this is the fact that individual Chinese scholars may have their preferences in terms of 
writing style (Connor, Ene and Traversa, 2016), and disciplinary specificities and school environments may engender different writing styles on students (McIntosh, Connor and Gokpinar-Shelton, 2017). Furthermore, some consider that employing the Anglophone gate-keeping approach of CR (Swales, 1997) to stereotype Chinese students' English writing is bias-ridden (Kirkpatrick and Xu, 2012).

O'Dwyer (2017) critiqued the idea that Confucian heritage has influenced current Chinese students' academic English learning, after evaluating the development of Confucianism over thousands of years, and analysing the educational status quo of many Confucian-oriented countries/regions. He concluded that the challenges faced by Confucian heritage students, including Chinese students, when studying in the West, are the result of government-controlled mass education differing from that of the West. Further, rather than blaming intercultural issues for students' difficulties with EAP, he cited a lack of training as the cause.

As previously noted, despite the on-going debate concerning the issue of intercultural differences in EAP, the extant empirical studies in the field of both English for Specified Purposes (ESP) (Aguilar, 2018) and EAP could be viewed as inadequate, partially due to the focus of the field on learners' needs, and their professional demands (Aguilar, 2018). Furthermore, few empirical studies have investigated intercultural issues in EAP, and those that have primarily concern academic writing (McIntosh, Connor and Gokpinar-Shelton, 2017; Xu, Huang and You, 2016; Connor, 2004), classroom discourse (Jund, 2010), and students' experiences (Dooey, 2010). Studies concerning how ESP/EAP textbooks process intercultural issues are even less common, although Bocanegra-Valle (2015) reported that the 10 ESP textbooks evaluated in his study all failed to include intercultural competence as a teaching outcome. Similarly, there is also a lack of studies concerning intercultural issues in Chinese-published EAP textbooks.

\section{Textbook analysis in EAP}

In the teaching of English as a Foreign Language (EFL)/English as a Second Language (ESL), textbooks are as essential as authoritative material resources (Gulliver, 2010). Moreover, textbooks are often employed as the basis of a syllabus (Harwood, 2005), and as training materials for inexperienced teachers (Cunningsworth, 1995). Textbooks are also considered to be necessary for teaching EAP, as they can demystify academic discourse for students facing new fields of study (BlajWard, 2014) and can, therefore, transform students into academic insiders (Alexander, Argent, and Spencer, 2008). However, EAP textbooks are much-maligned, and Harwood (2005, p.157) even argued that "EAP textbooks are failing teachers and students."

There are currently two approaches to textbook analysis in EAP: the corpus-based approach, and the critical approach (Bondi, 2016). Critics of EAP textbooks are primarily from the former approach; when corpus-based research is employed, many EAP textbooks are found to lack authentic academic language, and the use of unauthentic materials may hinder students facing academic realities (Stoller, 2016). Several studies on EAP textbooks have found shortcomings. In a study conducted by Paltridge (2002), EAP textbooks were found to fail in providing students with a generic structure for theses; Moreno (2003) discovered that the EAP textbooks examined in his study misrepresented causeeffect expressions; Wood and Appel (2014) found that textbooks failed to present academic keywords, and Holmes (1988), Hyland (1994), and McEnery and Kifle (2002) found that EAP textbooks teach modals and/or hedges inadequate/improperly. Furthermore, in a comparison of a corpus, researchers found the language employed in some EAP textbooks was unnaturally replicated in real lessons (Deroey, 2018; Salehzadeh, 2013; Flowerdew, 1992). Harwood (2005) concluded that this growing list of criticism catalysed into a fierce debate between the camps of strongly anti-textbooks, weakly anti-textbooks, and pro-textbooks in the EAP field. Harwood (2005) suggested that the weak antitextbook approach was best suited to the EAP field. Despite the prevailing opinions in favour of eliminating the use of EAP textbooks, many such textbooks were published, and are still being used, in China in the past five years.

Unlike the corpus-based studies, few studies using a critical-approach analysis seeking to reveal the ideologies and curricula they employ have been conducted on EAP textbooks (Bondi, 2016); the majority of the existing studies in this area feature English as a second language textbooks. For example, Gulliver (2010) found that certain ESL textbooks for new immigrants to Canada portray the experience of the immigrant as being one that goes from rags to riches. They also depict the immigrant's gratitude to their new country, which does not represent the experience of every immigrant. Moreover, Sokolik (2007) reported that some English grammar textbooks frequently tacitly spread consumerism in their sample sentences. Furthermore, EFL/ESL textbooks were 
generally found to support and present national policies, globalisation, Westernisation (Gulliver, 2010), racial prejudice, nationalistic ideologies (van Dijk, 2004), and sexist or gender bias (Sunderland, 2000; Matsuno, 2002) to varying extents. If a textbook presents a culture or an ideology in a manner that is alien to, or produces friction with readers, a misunderstanding, and resistance to learning might result (Boriboon, 2004; Canagarajah, 1993).

Feng and Byram (2002, p. 180) claimed that "analysis at the intercultural level of mutual representations and recognition by nature and foreign cultures" is the most critical dimension for studying intercultural communication in EFL textbooks. Therefore, the first research question of this present study sought to investigate the existence of $\mathrm{CoL}$ and $\mathrm{CR}$ in the textbooks concerned from a comparative perspective:

RQ 1. How are the students' home and target cultures, concerning CoL and CR, represented in the contents of the chosen EAP textbooks published in China?

However, researching the content of textbooks alone cannot provide a full picture, as textbooks represent only the intended curriculum, and not how they are employed by teachers and students (Harwood, 2017). A holistic textbook analysis involves the study of content, consumption (how teachers and students use textbooks), and production (issues related to the textbook authors and publication) (Harwood, 2014). Thus, alongside investigating the intercultural communication evident in the content of EAP textbooks, the present study also investigated the opinions of the textbook editors/authors, and EAP teachers and students:

RQ2. How do EAP textbook authors/editors perceive the processing of intercultural differences in the EAP textbooks they designed?

RQ3. How do teachers perceive and operationalise intercultural differences in teaching EAP, in line with the textbooks?

RQ4. To what extent are the challenges encountered by the students related to intercultural differences, and to what extent were they resolved using the textbooks?

\section{METHODS}

The authors of this present study employed convenience and snowball sampling to insure that they had access to the editors and users of the chosen textbooks. Two textbook series were selected for this study, and detailed information regarding their respective titles, publishers, and our access to the book series is shown in appendix 1. Two books from the Key Concepts Series, which were initially written by Western authors, and published by Heinle Cengage Learning (see Smith-Palinkas and CrohanFord, 2009; Vestri Solomon and Shelley, 2006) and imported and adapted by Chinese editors, who customised the books for Chinese EAP learners (see He, ed., 2017a; 2017b) were selected. This book series was used as the EAP textbook at the institution of the second author of the present study. The second author of the present study and some of his colleagues are the editors and writers of New Outlook College Reading and Writing 3 (Wang and $\mathrm{Xu}, 2015$ ), which claims to represent a bridging textbook for Chinese learners studying EAP. Therefore, some of these individuals, including the second author, were interviewed as editors and writers (see Appendix 2 for the participants' information, excluding that of the second author). An independent writer (EW1), who did not teach the Key Concepts series, was also involved in writing the book, and the authors of this present study also included her voice. However, it was not possible to access the users of New Outlook 3, despite liaising with the publisher. It was anticipated that interviewing the EAP teachers, both of whom were users of the Key Concepts Series, and editors/authors of New Outlook 3, may generate new insights. In order to address RQ1, a qualitative documentary analysis was employed. A content evaluation form was designed to clarify the possible mutual representations of the EAP students' home and target culture in the chosen textbooks based on the two primary components of intercultural differences (CR and CoL), (see Appendix 3.).

The authors analysed the textbooks following the Evaluation Form and coded the aspects related to $\mathrm{CR}$ and $\mathrm{CoL}$ with coloured stripes. The coding process included the stages presented below. Together with the categories of $\mathrm{CR}, \mathrm{AD}$, and $\mathrm{SD}$, the authors indicated the content that related to these categories, coding them with different coloured markers. They then completed the evaluation form. Content that delivered English academic reading and writing skills were coded as CR, as they denoted representations of the target culture's means of expression; Table 1 shows an example of text coded as CR. 
Table 1. An example from Key Concepts 1:

Listening, Note-taking, and Speaking Across the Disciplines (Source: He ed, 2017, p.9).

\begin{abstract}
What is a discourse marker?
Discourse markers are words or phrases that help listeners (and readers) understand the flow of information. These words and phrases signal essential pieces of information. They help us to understand and, more importantly, predict what will come next. We often use discourse markers when we speak. For instance, when you explain to your friends why you like a particular movie, you probably use discourse markers to add information.
\end{abstract}

Similarly, an example of content relating to academic learning skills and expectations included in the three books was coded as AD (See Table 2).

Table 2. An example from New Outlook College English:

Reading and Writing 3 (Source: Wang and Xu, 2015, p.147).

\begin{abstract}
Steps in scanning:
Keep the question in mind and anticipate what the answer can look like, e.g. a number, a data or several words.

Try to anticipate how the answer will appear and what clues you might use to help you locate the answer.

Use headings and any other aids that will help you identify which sections might contain the information you are looking for.

Selectively read and skip through sections of the passage.
\end{abstract}

Following the completion of their coding, the authors exchanged evaluation forms and discussed the results in order to achieve agreement regarding the coding. The coded contents were then organised into tables to illustrate the extent to which each book represented $\mathrm{CR}, \mathrm{AD}$, and $\mathrm{SD}$ in both the home and the target cultures. Table 4 presents the final table for CR in Key Concepts 1 . The content of each book is represented by three tables, one for each of the aforementioned three categories, and the results were listed according to the units.

In order to address RQ2 and RQ3, structured interview questions were designed and sent to the participating editor and writers/teachers via email or social media. The participants' right to anonymity and data confidentiality was explained in the invitation, as was the fact that they could complete the interview at their convenience. When necessary, the authors also followed up on the interview questions following the completion of the interviews. As previously mentioned, some of the teachers involved in this study were also authors of the New Outlook textbook 3. Therefore, the authors of this present study reminded them to discuss the issues concerned in the context of these separate roles. Further, focus group interviews were conducted to explore the extent to which the students involved in the study learned intercultural differences as a result of using the Key Concepts Series. As stated in the literature review, in order to attain a holistic understanding of a textbook, it is necessary to evaluate its content, production, and consumption. Such arrangement provided a theoretical triangulation (Bush, 2012). The corroboration between the evaluation form, the structured and semi-structured interviews, and the focus group interviews further enhanced the methodological triangulation (Bush, 2012). Moreover, the selection of the participants for this research in the subgroups of textbook editors, authors, and users, constituted a respondent triangulation (Bush, 2012). These multiple means of triangulation potentially improved the trustworthiness of the study.

\title{
FINDINGS AND DISCUSSION
}

\section{How are the students' home and target cultures, regarding CoL and CR, represented in the contents of the chosen EAP textbooks, published in China?}

Following the evaluation of the books, the authors found that in the three EAP textbooks, representations of $\mathrm{CR}$ and $\mathrm{AD}$ regarding the students' home culture were largely absent. Concerning $\mathrm{CR}$, both book series tended to present only the academic writing conventions stipulated by the target 
EAP culture, without reference to the learners' home culture writing practicum. For example, in Key Concepts 1: Reading and Writing Across the Disciplines, a prescriptive section titled, 'Get Ready to Write' introduced readers to the stages involved in the writing process, including pre-writing, writing, and post-writing (He, ed., 2017). This section was followed by exercises that required readers to practice English academic writing.

In New Outlook College English Reading and Writing 3, every chapter included a subsection titled 'Writing'. In the first chapter, this subsection introduced and explained the meaning, purpose, and features of academic writing. For example, when explaining 'objectivity' the book stated that written language is in general objective rather than personal. It, therefore, has fewer words that refer to the writer or the reader. This means that the primary emphasis should be on the information that you want to give and the arguments you want to make, rather than you. For that reason, academic writing tends to use a noun (and adjectives), rather than verbs (and adverbs). (Wang and Xu, 2015, p.24-5) The book adopted similar strategies to explain hedges and explicitness, introducing these issues without comparison to the Chinese approach to writing, and without heeding the potential mistakes made by Chinese students in writing. Concerning AD, each chapter of New Outlook College English Reading and Writing 3 included a section on critical thinking, but these sections lacked explanations in the context of either the home or the target culture. For example, the first critical thinking section in the book lacked justifications or explanations of why this is related to critical thinking and how Western universities regulate academic integrity, instead of listing several questions (see Table 3).

Table 3. An example of 'Critical Thinking' from Wang and Xu (2015, p.12)

1. Cheating in exams is generally prohibited in schools and universities.

Suppose you confront the following ethical dilemmas, what will you do and why?

(1) One of your close friends brings notes to the exam room and is about to cheat in the exam.

(2) A classmate who sits behind you in the exam room wants to copy your answer sheet.

(3) A dozen of your classmates happen to obtain a copy of the review highlight for a vital course, and they get high marks for the course. You only learn this after the exam.

Similarly, skills such as proofreading were mentioned in Key Concepts 1: Reading and Writing Across the Disciplines, and skills such as skimming and inferring were also explained in Outlook 3, although none of the books addressed the Chinese students' potential cultural distance in this context. Moreover, these examples are not an exhaustive list, and the authors of this study found that the books included neither SD nor information regarding how students should study or address the discourse of English academic writing.

\section{How do the EAP textbook authors/editors perceive the processing of intercultural differences in the EAP textbooks they designed?}

The interviews conducted with the authors of Outlook 3 revealed that the majority acknowledged the existence of intercultural differences for Chinese students studying EAP. The authors, WT1, WT2, and EW1 considered that one of the differences lies in the Chinese students' perception of academic integrity. As WT1 explained: Chinese students are not accustomed to using and quoting references in English academic writing, due to cultural differences. Traditionally, Chinese writing does not require an indication of the source of a reference, as the writers are seeking to create a sense of inclusiveness and informativeness for their readers in their writing. However, in English academic writing, proper referencing respects others' intellectual labour and property. Many Chinese students are warned about plagiarism when they do not reference correctly. (WT1 interview)

Moreover, a number of these authors noted that a further cultural difference is the way in which Chinese students' think when studying EAP. EW1 believed that Chinese students are unable to analyse problems independently, while WT1 considered that Chinese students are unable to challenge authority and to think critically. The cultural differences in Chinese students' academic writing were also highlighted by WT1, who claimed that "the structure of Chinese writing is generally spiral, but the structure of English writing is linear, so Chinese students are often influenced by the structure they use in Chinese writing" (WT1 interview). However, the author EWT1 objected to the notion that 
intercultural differences are responsible for causing Chinese students' weakness in academic integrity, expression, and thinking, arguing that "Chinese students were raised to write and to think statically. Therefore, they copy the writing prompts and use them in writing" (EWT1 interview). She insisted that these shortfalls of Chinese students can be overcome through systematic training at the university.

Almost all of the writers of Outlook 3 believed that Chinese students could obtain intercultural knowledge and critical thinking skills from the book. The writer WT1 cited an example she included in the textbook, involving a comparison between Western-style high-heel shoes, and the Chinese Qing Dynasty practice of female foot-binding, which intended to illustrate cultural differences and to enable students to transfer this understanding to their future critical thinking. Similarly, WT2 noted that a section at the end of each unit titled 'Bulletin board' (see example in Table 4) sought to develop students' discussion ability, and intercultural thinking.

Table 4. An example of a Bulletin board in Outlook 3 (Wang and Xu, 2015, p.53).

Bulletin board
Oral report
With the spread of cyber words among youngsters, many educators
worry that this disturbing trend will pose a threat to the purity of
our mother tongue. Are you a regular user of cyber words? If so, do
you think it harms the way you speak/write in Chinese? Please
make a 2-min oral report and don't forget to support your viewpoint
with personal experience or other examples.

Meanwhile, EW1 believed that Outlook 3 delivered intercultural differences through its presentation of English academic conventions and critical thinking skills. This view was echoed by EWT1, who considered that the examples and contexts provided in the textbook were customised for Chinese learners, and therefore the textbook was intercultural in its own right.

Although the writers of Outlook 3 believed that intercultural differences were included in the textbook, some also reflected that they had failed to highlight the possible intercultural issues, and therefore the users of the textbook may overlook this aspect. As WT2 noted, "it is difficult to convey the textbook writers' intention to the reader; the intercultural differences in the textbook should be more explicit" (WT2 interview). Meanwhile, the second author of the present study revealed the reason for the absence of explicit reminders of intercultural issues: "when we were designing the textbook, even in each unit, we had to adhere to a uniform structure stipulated by the editors, and intercultural differences were beyond the aim of the book." Furthermore, the chief editor of Outlook 3 stated that he did not support the inclusion of intercultural differences in the textbook, as "it is an English textbook, aiming to enable students to use English and to improve their thinking. If the intercultural issues are forced in the textbook, the book may become a chaotic amalgamation" (CE2 interview). He considered it to be a responsibility of the EAP teachers, rather than of the textbook, to teach students intercultural differences. However, the Outlook 3 editorial team only provided a limited amount of guidance in its use for teachers, and the teachers' companion to the textbook is no longer available.

\section{How do the teachers perceive and operationalise intercultural differences in teaching EAP, in line with the textbooks?}

As a teacher of Key Concepts 1, the second author explained that this book series focused on the academic skills of students, by presenting the genre and language of English academic writing. He also noted that specific topics in the book, for example, anthropology, philosophy, and literature, included intercultural values and knowledge. Together with his colleague, WT1, the second author utilised the series as a resource to initiate discussion of the differences between academic writing in China and the West. As WT1 explained, "the unit concerning literature includes a comparison between literature in the East and the West, which I later used as a warm-up to introduce students to the different structures in Chinese and English academic writing" (WT1 interview). Moreover, the textbooks constituted only a portion of the teachers' class materials for teaching intercultural differences. The author WT1 employed his students' writing as supplementary materials for demonstrating intercultural differences in academic writing: "In a writing task, I found that some students' references were missing, so I probed the reasons for this to discover whether it was due to 
the influence of their Chinese writing; then I taught the students CR between Chinese and English academic writing" (WT1 interview). Also, the second author used published journal articles as examples to familiarise his students with English academic writing and logic, referring to Chinese approaches to writing and thinking as a comparison.

\section{To what extent are the challenges encountered by the students related to intercultural differences, and to what extent are they resolved using the textbooks?}

Among the nine students involved in the interviews, eight believed that using Key Concepts 1 had improved their academic writing, particularly regarding the skills of summarising, paraphrasing, using discourse markers, synthesising, academic vocabularies, and sentence and paragraph structure. Some also believed that the textbook had expanded their academic vocabulary. However, it was noteworthy that one student observed, "I feel the textbooks are like self-study books; I do not think they have a significant impact on our EAP learning" (Student 6 interview). Since Student 6's EAP teacher was the second author of this study, and later WT2, it was possible to discover that the pedagogy they employed to teach EAP was a form of project-based learning (PBL), in which their students conducted empirical studies, and wrote academic reports under their teachers' supervision. Hence, the EAP textbook did not constitute the entirety of the pedagogy as the students also engaged in extracurricular self-study.

All nine of the first-year students interviewed confirmed that the means of studying EAP differed from that of their foundation education. Student 4 noted that "in high school, we learn everything for exams." Student 5 supported this: "we rote-learn English words and grammar, and English is more of a tool for passing exams than a tool for use." Moreover, Student 1 observed that, in high school, the teacher is the centre of attention, and Student 2 noted that "teachers talked throughout the lessons...now in EAP we have to do research and participate actively in projects." While the second author of this study observed that many of his students became accustomed to the EAP learning approach, and performed well, some of the students experienced struggle and confusion: "I was not sure what EAP meant and what constituted the term "academic" (Student 3 interview); and "in the first semester of EAP, I reluctantly followed the teachers' demands concerning the writing format, but the way I wrote was stiff, and even now I am still a bit confused... I could not look at things critically; why should I be critical? It restricted my EAP" (Student 5 interview).

The content analysis of the textbooks found that none of the textbooks considered SD, and only $\mathrm{AD}$ and $\mathrm{CR}$ included the target EAP culture. Therefore, only English academic writing and specific EAP study skills were introduced, without connecting these with the academic writing style and study habits of the students' home culture. This imbalance reflects and supports Byram's (2014) criticism concerning the public misunderstanding of inter-cultural matters, in which more weight is ascribed to the exploration of otherness, than to self-introspection. This phenomenon was echoed by Aguilar (2018), who highlighted the absence of intercultural competence in the ESP field, and the absence of intercultural issues in ESP textbooks observed by Bocanegra-Valle (2015). This absence may be related to the genre of ESP/EAP, as the field was created to address students' academic and professional demands in the target discourse (Aguilar, 2018). In the interviews with the authors and editor of Outlook 3, findings revealed that the editorial team was inconsistent in their perception and operationalisation of intercultural differences. The chief editor believed that intercultural differences was not the aim of the textbook, since its focus was English academic language, while the authors such as EW1 and EWT1 believed that the practice of teaching the English language to Chinese students is in itself intercultural. The majority of the authors believed it is necessary to teach EAP students' intercultural differences, but claimed that the structure established by the chief editor restricted their design, and they were unable to include explicit intercultural remarks or content. Hence, some of the interviewees observed that the inclusion of intercultural differences in Outlook 3 was dependent on the interpretations of the users themselves, and this was exacerbated by the fact that the Teachers' Companion to Outlook 3 was no longer in print. Therefore, the production team of Outlook 3 did not facilitate the training of their users regarding teaching intercultural differences, and in the absence of sufficient training, teachers might misuse the textbooks (Lazar, 2011).

It was noteworthy that, among the Outlook 3 authors, EWT1 claimed that the challenges that Chinese EAP learners face are not caused by intercultural differences, but by their lack of training. This reflected O'Dwyer's (2017) view that the challenges in English academic education faced by students from Confucian cultures are due to the different education and training such students receive in their home country. Moreover, different elements of training and education can be culturally 
underpinned, as they can be assigned differing degrees of attention since culture is a "code of practical instructions whereby members are permitted to talk meaningfully about some things while ignoring others" (Lemert, 1995, p.174). The teacher using the Key Concepts Series involved in this study taught intercultural differences, and particularly $\mathrm{AD}$ and $\mathrm{CR}$, either by employing authentic materials or by adapting the textbooks, which reflected Harmer's claim $(2001, p .8)$ that textbooks function only as "spurs to creativity." Moreover, the textbooks did not play a key role in the teachers' EAP curriculum, as they employed PBL to engage their students through research projects, in which the students consulted authentic databases, with the textbooks serving as additional resources. This approach reflected the weak anti-textbook strand within the EAP textbook field, cited by Harwood (2005, p. 154): "while the textbook can provide structure, its syllabus should be flexible enough to allow the local teachers to input additional locally appropriate content." The PBL EAP pedagogy employed by the teachers in the present study was considered to be useful by their students for adapting them to the EAP style of teaching, which concurs with Aguilar's (2018) argument concerning the value of PBL for improving ESP students' intercultural competence. Hence, the teachers involved in the present study considered that a combination of resources was important for teaching intercultural differences to their EAP students, which echoes Aguilar's (2018, p.25) view that ESP teachers themselves are "the best prepared professionals for teaching intercultural skills".

The students interviewed in this study reported that the Key Concepts primary value was in teaching them academic English. While they were unaccustomed to studying via a PBL pedagogy, as the course progressed, their teacher observed that they gradually overcame their difficulties. However, at the time of the study, some of the students remained confused about the concept of academia, and the necessity for critical thinking, both of which are aspects that their teachers, as linguists, might find challenging to address, and which the textbooks failed to cover. In general, the textbooks involved in the present study adopted a top-down approach to instruction in the forms of academic writing and skills, tending to dismiss the intercultural issues involved, missing a mutual representation of $\mathrm{AD}, \mathrm{SD}$, and $\mathrm{CR}$, and marginalising readers with different backgrounds. If the textbooks altered their approach and sought to demystify the globalised jargon, such as 'critical thinking' and 'academia', in terms suitable for the local Chinese students' beliefs and schema, this problem might be alleviated. This necessity for a change in approach from top-down to bottom-up global-local negotiation was highlighted by the critical EAP (CEAP) scholar Macallister (2016), who argued that CEAP could free local students from marginalisation. Hence, from a CEAP perspective, the EAP textbooks published in China should be more intercultural.

\section{CONCLUSION}

The spread of EAP teaching in China has catalysed a surge in EAP textbook publication. However, textbook analysis of intercultural issues is rare in this field. The present study selected Chinese students' potential CoL and CR as infiltrating points and analysed the content, production, and consumption of two series of EAP textbooks. It found that intercultural differences were absent from both series. The editorial team of one series maintained inconsistencies towards the inclusion of intercultural differences, obstructing their communication with, and guidance to, the textbook users. Meanwhile, the teachers as users of the other textbook series involved in this study employed the textbooks as supplementary materials for teaching EAP. Nevertheless, the continued confusion on the part of some of the students involved in the study highlighted the desirability for future textbooks to render intercultural differences in a CEAP manner.

\section{ACKNOWLEDGEMENT}

This study is funded by the project Study of the Language Industries in Macau (MF1916) of Fundacao Macau. The authors would like to express their sincere thanks to The Foreign Language Education and Research Centre at City University of Macau and Dr Paul Stapleton at Education University of Hong Kong for his proofreading and suggestions.

\section{REFERENCES}

Aguilar, M. (2018). Integrating Intercultural Competence In Esp And Emi: From Theory To Practice. ESP Today-Journal of English for Specific Purposes At Tertiary Level, 6(1), 25-43.

Alexander, O., Argent, S. \& Spencer, J. (2008). EAP essentials. Reading: Garnet. 
Blaj-Ward, L. (2014). Researching contexts, practices and pedagogies in English for academic purposes. Hampshire: Palgrave Macmillan.

Bloch. J. (2008). Plagiarism across cultures: is there a difference? In C. Eisner \& M. Vicinus. (Eds). Originality, imitation, and plagiarism: teaching writing in the digital age. Ann Arbor, MI: University of Michigan Press.

Bocanegra-Valle, A. (2015). La competencia intercultural en los manuales de texto con fines específicos a través de la evaluación de sus indicadores y niveles de dominio. The intercultural competence in ESP textboks through the assessment of indicators and mastery level. Cuadernos de Filología Francesa, 26, 29-43.

Bondi, M. (2016). Textbooks. In K. Hyland, \& P. Shaw (Eds.), The Routledge handbook of English for academic purposes (pp. 323-334). New York/London: Routledge.

Boriboon, P. (2004). We would rather talk about plaa raa than hamburgers': Voices from low-proficient EFL learners in a rural Thai context. In 11th Sociocultural Theory and Second Language Learning Research Conference, University of Nijmegen, Netherlands.

Bush, T. (2012). Authenticity in Research: Reliability, Validity and Triangulation. In A.J., Briggs, M. Coleman., \& M. Morrison (Eds.), Research Methods in Educational leadership \& Management (pp. 75-89). London: Sage.

Byram, M. (2014). Twenty-five years on-from cultural studies to intercultural citizenship. Language, culture and curriculum, 27(3), 209-225.

Canagarajah, A. S. (1993). American textbooks and Tamil students: Discerning ideological tensions in the ESL classroom. Language, Culture and Curriculum, 6(2), 143-156.

Connor, U. (1996). Contrastive Rhetoric Cross-cultural aspects of second-language writing. Cambridge: Cambridge University Press.

Connor, U.(2004). Contrastive rhetoric: old and new directions. In S. Aydelott, N. Kassagby, Z. Ibrahim (Eds.), Contrastive Rhetoric: Issues, Insights, and Pedagogy (pp. 1-24). Cairo: The American University in Cairo Press.

Connor, U. (2011). Intercultural rhetoric in the writing classroom. Ann Arbor: University of Michigan Press.

Connor, U., Ene, E., \& Traversa., A. (2016). Intercultural Rhetoric. In K.Hyland, \& P. Shaw (Eds.), The Routledge handbook of English for academic purposes (pp. 270-282). New York/London: Routledge

Cortazzi, M. \& Jin, L.X. (1996) Cultures of Learning: Language Classrooms in China. In H. Coleman (Eds.), Society and the Language Classroom (pp.169-206). Cambridge: Cambridge University Press.

Cunningsworth, A. (1995). Choosing your textbook. Oxford; Heinenmann

de Chazal, E. (2014). English for Academic Purposes. Oxford: Oxford University Press.

Deroey, K. L. (2018). The representativeness of lecture listening coursebooks: Language, lecture authenticity, research-informedness. Journal of English for Academic Purposes, 34, 57-67.

Dooey, P. (2010). Students' perspectives of an EAP pathway program. Journal of English for Academic Purposes, 9(3), 184-197.

Durkin, K. (2011). Adapting to Western Norms of Critical Argumentation and Debate. In L.X., Jin \& M. Cortazzi, (Eds.), Researching Chinese learners (pp. 274-291). Palgrave Macmillan, London.

Emerson, J. (2018, May). EAP in China: How previous learning experiences, family and culture define appropriate methods in the transnational era. Parallel Session Presentation at The International Conference on "English Language Education in the Chinese Context", The Education University of Hong Kong, Hong Kong.

Feng, A., \& Byram, M. (2002). Authenticity in College English textbooks-An intercultural perspective. RELC Journal, 33(2), 58-84.

Flowerdew, J. (1992). Definitions in science lectures. Applied linguistics, 13(2), 202-221.

Gao, L. (1998). Cultural context of school science teaching and learning in the People's Republic of China. Science Education, 82(1), 1-13.

Grimshaw, T. (2007). Problematizing the construct of 'the Chinese learner': Insights from ethnographic research. Educational Studies, 33(3), 299-311.

Gulliver, T. (2010). Immigrant success stories in ESL textbooks. TESOL Quarterly, 44(4), 725-745.

Harmer, J. (2001). The practice of English language teaching. London/New York: Pearson Education.

Harwood, N. (2005). What do we want EAP teaching materials for?. Journal of English for Academic Purposes, 4(2), 149-161. 
Harwood, N. (2014). Content, Consumption, and Production: Three Levels of Textbook Research. In N. Harwood (Ed.). English Language Teaching Textbooks: Content, Consumption, Production (pp. 1-41). Hampshire: Palgrave Macmillan.

Harwood, N. (2017). What can we learn from mainstream education textbook research?. RELC Journal, 48(2), 264-277.

He, L. Z. (Ed.) (2017a). Xinbian Daxue Hexin Yingyu Tingshuo Jiaocheng (Shang) [Key Concepts 1: Listening, note taking, and speaking across the disciplines] (English version original by Vestri Soloman \& Shelly, 2006 published by Heinle Cengage Learning). Beijing: Gaodeng Jiaoyu Chuban she.

He, L. Z. (Ed.) (2017b). Xinbian Daxue Hexin Yingyu Duxie Jiaocheng (Shang) [Key concepts 1: Reading and writing across the disciplines] (English version original by Smith-Palinkas \& Croghan-Ford, 2009 published by Heinle Cengage Learning). Beijing: Gaodeng Jiaoyu Chuban she.

Holmes, J. (1988). Doubt and certainty in ESL textbooks. Applied linguistics, 9(1), 21-44.

Hyland, K. (1994). Hedging in academic writing and EAF textbooks. English for specific purposes, 13(3), 239-256.

Jin, L.X. \& Cortazzi, M. (1998). The culture the learner brings: a bridge or a barrier? In M. Byram, \& M, Fleming (Eds). Language learning in intercultural perspective: approaches through drama and ethnography (pp. 98-118).Cambridge: Cambridge University.

Jin, L. X., \& Cortazzi, M. (2003). English language teaching in China: A bridge to the future. In W. K. Ho \& R. Y. L. Wong (Eds.), English Language Teaching in East Asia Today: Changing policies and practices (pp. 131-145). Singapore: Times Academic Press.

Jin, L. X., \& Cortazzi, M. (2006). Changing practices in Chinese cultures of learning. Language, culture and curriculum, 19(1), 5-20.

Jund, A. (2010). Toward a Pedagogy of Intercultural Understanding in Teaching English for Academic Purposes. Tesl-EJ, 14(1), 1-13.

Jung, I. (2009). Ethical judgments and behaviors: Applying a multidimensional ethics scale to measuring ICT ethics of college students. Computers \& Education, 53(3), 940-949.

Kaplan, R. B. (1966). Cultural thought patterns in inter-cultural education. Language learning, 16(1-2), $1-20$.

Kirkpatrick, A., \& Xu, Z. (2012). Chinese rhetoric and writing. An introduction for language teachers. South Carolina: Parlor Press.

Lázár, I. (2011). Teachers' beliefs about integrating the development of intercultural communicative competence in language teaching Case studies of Hungarian pre-service English teachers. ForumSprache, 2011(5), 112-126.

Lemert, C. (1995). Sociology after the crisis. Boulder, CO: Westview Press.

Li, X., \& Cutting, J. (2011). Rote learning in Chinese culture: Reflecting active Confucian-based memory strategies. In L. X. Jin \& M. Cortazzi (Eds.). Researching Chinese learners: Skills, Perceptions and Intercultural Adaptations (pp. 21-42). Palgrave Macmillan, London.

Liu, N. F., \& Littlewood, W. (1997). Why do many students appear reluctant to participate in classroom learning discourse? System, 25(3), 371-384.

Macallister, C. J. (2016). Critical Perspectives. In K. Hyland, \& P. Shaw (Eds.), The Routledge handbook of English for academic purposes (pp. 283-294). New York/London: Routledge.

Maley, A. (1996). Xanadu -'A miracle of rare device': The teaching of English in China. In J. M. Valdes (Ed.), Culture bound: Bridging the cultural gap in language teaching (pp.77-78). Cambridge: Cambridge University Press.

Matalene, C. (1985). Writing Teacher in China. College English, 47(8), 789-808.

Matsuno, S. (2002). Sexism in Japanese radio business English program textbooks. JALT journal, 24(1), 83-97.

McEnery, T., \& Kifle, N. A. (2002). Epistemic modality in argumentative essays of second-language writers. In J. Flowerdew (Ed.). Academic Discourse (pp.182-195). Harlow: Longman.

McIntosh, K., Connor, U., \& Gokpinar-Shelton, E. (2017). What intercultural rhetoric can bring to EAP/ESP writing studies in an English as a lingua franca world. Journal of English for Academic Purposes, 29, 12-20.

Moreno, A. I. (2003). Matching theoretical descriptions of discourse and practical applications to teaching: the case of causal metatext. English for Specific Purposes, 22(3), 265-295.

Nisbett, R.E. (2003). The geography of thought: How Asians and Westerners think differently and why. New York: Free Press. 
O'Dwyer, S. (2017). Deflating the 'Confucian Heritage Culture' thesis in intercultural and academic English education. Language, Culture and Curriculum, 30(2), 198-211.

Paltridge, B. (2002). Thesis and dissertation writing: an examination of published advice and actual practice. English for Specific Purposes, 21, 125-143

Parris-Kidd, H., \& Barnett, J. (2011). Cultures of learning and student participation: Chinese learners in a multicultural English class in Australia. In L.X., Jin \& M, Cortazzi. (Eds.), Researching Chinese learners (pp. 169-187). Palgrave Macmillan, London.

Rao, N. \& Chan, C. K. K. (2009). Moving Beyond Paradoxes: Understanding Chinese Learners and Their Teachers. In C.K.K. Chan \& N. Rao (Eds.). Revisiting The Chinese Learner Changing Contexts, Changing Education (pp. 3-32). Hong Kong: Springer.

Ryan, J. (2011). Teaching and learning for international students: Towards a transcultural approach. Teachers and Teaching, 17(6), 631-648.

Salehzadeh, J. (2013). Academic listening strategies: A guide to understanding lectures. Ann Arbor: University of Michigan Press.

Salili, F. (1996). Achievement Motivation: a cross-cultural comparison of British and Chinese students. Educational Psychology, 16(3), 271-279.

Scollon, R. (1991, March). Eight legs and one elbow: Stance and structure in Chinese English compositions. Paper presented at the International Reading Association Second North American Conference on Adult and Adolescent Literacy, Banff, Canada.

Shon, P. C. (2015). How to read journal articles in the social sciences: a very practical guide for students. London: Sage.

Singh, P., \& Doherty, C. (2004). Global cultural flows and pedagogic dilemmas: Teaching in the global university contact zone. TESOL Quarterly, 38(1), 9-42.

Smith-Palinkas, B., \& Croghan-Ford, K. (2009). Key concepts 1: Reading and writing across the disciplines. Boston: Heinle, Cengage Learning.

Sokolik, M. E. (2007). Grammar Texts and Consumerist Subtexts. TESL-EJ, 11(2), 1-9.

Stoller, F. L. (2016). EAP Materials and Tasks. In K. Hyland, \& P. Shaw (Eds.), The Routledge handbook of English for academic purposes (pp. 577-591). New York/London: Routledge.

Sunderland, J. (2000). New understandings of gender and language classroom research: Texts, teacher talk and student talk. Language Teaching Research, 4(2), 149-173.

Swales, J. M (1997). English as "Tyrannosaurus Rex". World Englishes, 16 (3), 373-82.

van Dijk, T. A. (2004). Racism, discourse and textbooks: The coverage of immigration in Spanish textbooks. Paper presented at the Symposium on Human Rights in Textbooks, Istanbul, Turkey. Retrieved from www.discourses.org/Unpublished articles Teun A van Dijk.html

Vestri Solomon, E. V., \& Shelley, J. L. (2006). Key Concepts 1: Listening, Note Taking, and Speaking Across the Disciplines. Boston: Heinle Cengage Learning

Wallace, M., \& Wray, A. (2016). Critical reading and writing for postgraduates. London: Sage.

Wang, N. (2018). Xueshu yingyu de shishi feifei-Fudan daxue cai jigang jiaoshou fangtan lu. [The right and wrong of academic English - An interview with Professor Cai Jiagang, Fudan University]. Zhongguo Daxue Jiaoxue, 2, 47-62.

Wang, Y. \& Xu, L. J. (2015). Xin Siwei Daxue Yingyu Duxie Jiaocheng 3 [New Outlook College English reading and Writing 3]. Beijing: Foreign Language Press.

Watkins, D. A. (2009) Motivation and Competition in Hong Kong Secondary Schools: The Students' Perspectives. In In C.K.K. Chan \& N. Rao (Eds.). Revisiting The Chinese Learner Changing Contexts, Changing Education (pp. 71-88). Hong Kong: Springer.

Wood, D. C., \& Appel, R. (2014). Multiword constructions in first year business and engineering university textbooks and EAP textbooks. Journal of English for Academic Purposes, 15, 1-13.

Xu, M., Huang, C., \& You, X. (2016). Reasoning patterns of undergraduate theses in translation studies: An intercultural rhetoric study. English for Specific Purposes, 41, 68-81.

Yang, S. C. (2012). Ethical academic judgments and behaviors: applying a multidimensional ethics scale to measure the ethical academic behavior of graduate students. Ethics \& Behavior, 22(4), 281296.

\section{APPENDIX}

Appendix 1: Detailed information of the selected EAP textbooks 


\begin{tabular}{|c|c|c|c|c|c|c|}
\hline $\begin{array}{l}\text { Book } \\
\text { Series }\end{array}$ & Book name & $\begin{array}{l}\text { Editor } \\
\text { in } \\
\text { China }\end{array}$ & Publisher & $\begin{array}{l}\text { Target } \\
\text { readers }\end{array}$ & $\begin{array}{l}\text { Access to } \\
\text { the book } \\
\text { series } \\
\text { production } \\
\text { team }\end{array}$ & $\begin{array}{l}\text { Access to } \\
\text { book } \\
\text { users }\end{array}$ \\
\hline \multirow[t]{2}{*}{$\begin{array}{l}\text { Key } \\
\text { Concepts }\end{array}$} & $\begin{array}{l}\text { Key Concepts 1: } \\
\text { Reading and } \\
\text { Writing Across the } \\
\text { Disciplines }\end{array}$ & $\begin{array}{l}\text { He, ed. } \\
(2017 a)\end{array}$ & \multirow[t]{2}{*}{$\begin{array}{l}\text { Higher } \\
\text { Education } \\
\text { Press } \\
\text { (China) }\end{array}$} & \multirow[t]{2}{*}{$\begin{array}{l}\text { Beginner } \\
\text { level EAP } \\
\text { students }\end{array}$} & \multirow[t]{2}{*}{ No } & \multirow[t]{2}{*}{ Yes } \\
\hline & $\begin{array}{l}\text { Key Concepts 1: } \\
\text { Listening, Note } \\
\text { Taking, and } \\
\text { Speaking Across } \\
\text { the Disciplines }\end{array}$ & $\begin{array}{l}\text { He, ed. } \\
\text { (2017b) }\end{array}$ & & & & \\
\hline $\begin{array}{l}\text { New } \\
\text { Outlook }\end{array}$ & $\begin{array}{l}\text { College Reading } \\
\text { and Writing } 3\end{array}$ & $\begin{array}{l}\text { Wang } \\
\text { and Xu } \\
(2015)\end{array}$ & $\begin{array}{l}\text { Foreign } \\
\text { Language } \\
\text { Press } \\
\text { (China) }\end{array}$ & $\begin{array}{l}\text { Beginner } \\
\text { level EAP } \\
\text { students }\end{array}$ & Yes & No \\
\hline
\end{tabular}

Appendix 2: Information about the Outlook 3 editorial team, and the teachers of the Key Concepts Series

\begin{tabular}{llllll}
\hline Name & Position & $\begin{array}{l}\text { Role in Key } \\
\text { Concepts Series }\end{array}$ & $\begin{array}{l}\text { Role in New } \\
\text { Outlook } \\
\text { Series }\end{array}$ & $\begin{array}{l}\text { Educational } \\
\text { background }\end{array}$ & $\begin{array}{l}\text { Previous } \\
\text { teaching } \\
\text { experience }\end{array}$ \\
\hline CE2 & Professor & N/A & Editor & MA TESOL & $\begin{array}{l}\text { Taught EFL } \\
\text { and EAP }\end{array}$ \\
\hline WT1 & $\begin{array}{l}\text { Associate } \\
\text { Professor }\end{array}$ & Teacher & Writer & $\begin{array}{l}\text { PhD Intercultural } \\
\text { Communication }\end{array}$ & Taught EAP \\
\hline EWT1 & Lecturer & Teacher & Writer & $\begin{array}{l}\text { PhD Applied } \\
\text { Linguistics }\end{array}$ & Taught EAP \\
& Lecturer & Teacher & Writer & $\begin{array}{l}\text { PhD Applied } \\
\text { Linguistics }\end{array}$ & Taught EAP \\
& & & & $\begin{array}{l}\text { MA Applied } \\
\text { Linguistics }\end{array}$ & Taught EFL
\end{tabular}

Appendix 3: The initial EAP textbook evaluation form

\begin{tabular}{lllll}
\hline EAP TEXTBOOK EVALUATION FORM FOR INTERCULTURAL DIFFERENCES \\
\hline INTERCULTURAL & TEXTBOOK TITLE: & Author(s)/Editor(s): \\
DIFFERENCES & $\begin{array}{l}\text { Publisher: } \\
\text { Evaluator: }\end{array}$ \\
& $\begin{array}{l}\text { The representation of home } \\
\text { culture }\end{array}$ & The representation of target culture \\
\hline & Page Content Remark & Page Content & Remark \\
\hline
\end{tabular}

CR

\section{CoL, \\ AD including AD and SD \\ SD}

Appendix 4: A sample form reporting the CR in Key Concepts 1 


\begin{tabular}{|c|c|c|}
\hline \multirow{2}{*}{$\begin{array}{l}\text { Key Concepts 1: Listening, Note Taking, } \\
\text { and Speaking Across the Disciplines }\end{array}$} & \multicolumn{2}{|l|}{ Category: CR } \\
\hline & $\begin{array}{l}\text { Home culture } \\
\text { means of } \\
\text { expression }\end{array}$ & $\begin{array}{l}\text { Target culture means of } \\
\text { expression }\end{array}$ \\
\hline $\begin{array}{l}\text { Unit } 1 \text { The Student Experience: Success in } \\
\text { College }\end{array}$ & None & $\begin{array}{l}\text { Introducing Discourse } \\
\text { Markers }\end{array}$ \\
\hline Unit 2 From the Social Sciences: Psychology & None & None \\
\hline $\begin{array}{l}\text { Unit } 3 \text { From Business: International Trade } \\
\text { and Marketing }\end{array}$ & None & $\begin{array}{l}\text { Discourse Markers: } \\
\text { Sequencing }\end{array}$ \\
\hline $\begin{array}{l}\text { Unit } 4 \text { From the Social Sciences: American } \\
\text { Government }\end{array}$ & None & $\begin{array}{l}\text { Discourse Markers: } \\
\text { Transitions }\end{array}$ \\
\hline Unit 5 From the Social Sciences: Philosophy & None & None \\
\hline $\begin{array}{l}\text { Unit } 6 \text { From the Social Sciences: Cultural } \\
\text { Anthropology }\end{array}$ & None & $\begin{array}{l}\text { Discourse Marker and } \\
\text { Commonly Used } \\
\text { Expressions }\end{array}$ \\
\hline
\end{tabular}

